\title{
Peningkatan Nilai Tambah Ikan Lele melalui Pemberdayaan Perempuan untuk Meningkatkan Ekonomi di Kecamatan Lingsar
}

\author{
Baiq Fitria Rahmiati ${ }^{1}$, Anthony Anggrawan ${ }^{2}$, Wayan Canny Naktiany ${ }^{3}$, Sirojul Hadi ${ }^{4}$, \\ Nurul Hidayah ${ }^{5}$, Hasbullah ${ }^{6}$ \\ baiqfitria@universitasbumigora.ac.id ${ }^{1}$, \\ anthony.anggrawan@universitasbumigora.ac.id ${ }^{2}$, \\ nurulhidayah@universitasbumigora.ac.id ${ }^{3}$, wayancanny@universitasbumigora.ac.id ${ }^{4}$ \\ sirojulhadi@universitasbumigora.ac.id ${ }^{5}$, hasbullah@universitasbumigora.ac.id ${ }^{6}$
}

1,2,3,4,5,6 Universitas Bumigora

\begin{abstract}
Article History:
Received: 26-11-2021

Revised: 04-01-2022

Accepted: 13-01-2022
\end{abstract}

\begin{abstract}
This community service activity aims to find solutions for problems faced by the people of Batu Kumbung Village in improving family economy, by making various processed products based on local food (catfish). Fresh water fishery products found in Batu Kumbung Village are very abundant, especially catfish. The people of Batu Kumbung Village already have a joint business group, but the products produced are still very limited. In this regard, then it is necessary to provide catfish water processing skills to the community in Batu Kumbung Village so that it is expected to increase knowledge and skills that can used to improve the economy. Methods used in this activities, are: Providing training material modules to be implemented; The presentation of the material is in accordance with the contents of the recipe book plus material on food nutrition, hygiene and sanitation, kitchen management, and product packaging and online marketing related to the business to be run. The output target of the activity is that participants can increase their knowledge and skills in producing various catfish; Participants are able to organize and manage the business them properly and sustainably; the presence of a variety of local food-based specialty preparations which can be used as souvenirs for consumers.
\end{abstract}

Keywords: catfish, improvement, business, fishery product

\section{Pendahuluan}

Dalam rangka peningkatan sumber daya manusia (SDM) dan taraf hidup yang lebih baik, pendidikan dan pelatihan memegang peranan penting, seperti yang dijelaskan dalam UU Sistem Pendidikan Nasional No. 20 Pasal 26 tahun 2006. Hal ini juga diperkuat dari hasil Rakernas PKK II 1984 yang bertujuan untuk memperbaiki taraf dan penghidupan keluarga. Dimana dalam hal ini dibutuhkan pengetahuan dan keterampilan sehingga dapat memenuhi kebutuhan hidup yang memadai. Sesuai dengan hal tersebut, mengingat peran masyarakat dewasa ini dalam pembangunan sudah tidak lagi dikaitkan hanya dengan bekerja dan menjalankan tugas sebagai pegawai pada suatu instansi pemerintah. Peran masyarakat juga sangat kuat jika mereka dapat mandiri dengan segala kemampuan yang dimiliki, yaitu pengetahuan dan keterampilan. Kemampuan masyarakat perlu lebih dikembangkan dalam 
rangka meningkatkan peranan dan tanggung jawabnya pada pembangunan melalui penyuluhan, pengetahuan, dan beberapa bentuk pelatihan keterampilan. Terutama untuk dapat lebih memanfaatkan kesempatan di berbagaibidang. Dengan demikian, dapat meningkatkan partisipasinya dan memberikan sumbangan yang sebesarbesarnya bagi pembangunan bangsa. Seiring dengan hal di atas, maka peranan masyarakat dalam pembangunan berkembang selaras dan serasi dengan perkembangan ilmu pengetahuan (Notoatmodjo, 2003).

Provinsi Nusa Tenggara Barat (NTB) memiliki perairan tawar yang sangat luas dan berpotensi besar untuk usaha budidaya berbagai macam jenis ikan air tawar. Sumber daya perairan di NTB meliput perairan umum (sungai, waduk dan rawa), sawah (mina padi), dan kolam. Dengan potensi perairan air tawar yang sangat besar, NTB baru mampu memproduksi sekitar 1,7 juta ton ikan air tawar pertahun. Potensi perairan di NTB yang besar diiringi oleh pertumbuhan penduduk, konsumsi ikan air tawar pun meningkat dari tahun ke tahun (Badan POM, 2018 \& Eko Suparmiyati et al, 2017).

Kabupaten Lombok Barat merupakan salah satu daerah yang memiliki potensi untuk bisnis budidaya ikan, selain karena permintaan terhadap produk ikannya cukup besar, di daerah Kabupaten Lombok Barat juga masih banyak lahan yang berpotensi digunakan untuk budidaya ikan. Kegiatan budidaya air tawar di Kabupaten Lombok Barat cukup potensial untuk terus dikembangkan karena menjanjikan dari segi ekonomis maupun dari segi daya dukung sumber daya alam kegiatan budidaya ikan air tawar di Kabupaten Lombok Barat terdiri dari atas budidaya ikan pada kolam air tenang dan keramba adapun Kecamatan yang paling menonjol dalam produksi dan budidaya ikan air tawar di Kabupaten Lombok Barat adalah Kecamatan Lingsa (IKP, 2020).

Lele merupakan salah satu ika tawar yang jumlahnya melimpah di Desa Batu Kumbung. Lele sangat mudah diolah dan dibuat menjadi berbagai macam jenis olahan. Kandungan gizi pada ikan lele per100 gram yaitu 18 gram protein, 3 gra leak, 23 iligtam asam lemak omega 3, 337 miligram asam lemak omega 6, dan 5,9 gram zat besi (Baiq Fitria Rahmiati, 2019).

Melalui kegiatan peningkatan pengetahuan dan keterampilan yang dimiliki diharapkan dapat memberikan peluang kepada masyarakat untuk meningkatkan nilai jual dari makanan kudapan yang selama ini telah mereka produksi. Selain itu, perlu adanya perluasan pemasaran, sehingga memberi peluang untuk peningkatan penghasilan. Berdasarkan observasi yang telah dilakukan, diketahui beberapa permasalahan di masyarakat. Antara lain: kurangnya keterampilan ibu-ibu dan remaja putri dalam mengolah dan menyajikan makanan berbahan baku ikan air tawar, pengetahuan mengenai cara https://journal.universitasbumigora.ac.id/index.php/ADMA 
produksi makanan yang baik masih kurang, penerapan manajemen usaha belum ada, serta variasi olahan masih kurang. Oleh sebab itu, perlu kiranya warga setempat diberikan pendidikan dan pelatihan keterampilan agar mereka dapat meningkatkan kemampuannya menghasilkan produk berkualitas sekaligus meningkatan perekonomian keluarga. Warga Desa Batu Kumpbung memerlukan transfer pengetahuan dan teknologi tentang pengolahan pangan yang sehat, higienis dan aman. Diharapkan dengan ini mampu menghasilkan produk yang berkualitas sesuai permintaan konsumen (Rahmiati et al., 2018).

Berdasarkan identifikasi permasalahan yang dikemukakan di atas, maka kami Tim Pengabdian Universitas Bumigora melakukan kegiatan tentang pelatihan pembuatan produk Ikan Lele untuk meningkatkan perekonomian di Desa Batu Kumbung.

\section{Metode}

Kegiatan pengabdian kepada masyarakat ini bertujuan untuk memberikan solusi dari permasalahan yang dihadapi oleh masyarakat Desa Batu Kumbung dalam meningkatkan ekonomi keluarga, yaitu dengan cara membuat aneka olahan yang beranekaragam berbasis bahan pangan lokal ikan lele. Hasil perikanan air tawar yang terdapat di Desa Batu Kumbung sangat melimpah, terutama ikan lele. Masyarakat Desa Batu Kumbung telah memiliki kelompok usaha bersama, namun produk yang dihasilkan masih sangat terbatas. Adapun usulan model kegiatan PKM adalah Pelatihan peningkatan kreatifitas dalam membuat aneka olahan Ikan Lele di Desa Batu Kumbung. Kegiatan ini dimulai dari perencanaan, pelaksanaan hingga pengelolaan usaha. Metode pelaksaan yang dilakukan dalam kegiatan PKM yaitu dengan memberikan modul materi pelatihan yang akan dilaksanakan, Penyajian materi sesuai dengan isi buku resep dan ditambah mengenai materi gizi makanan, hygine dan sanitasi, manajemen dapur, pengemasan produk dan pemasaran online terkait usaha yang akan dijalankan. Berikut uraian diagram blok langkah-langkah dalam memberikan solusi yang ditawarkan untuk mengatasi beberapa permasalahan di Desa Kumbung.

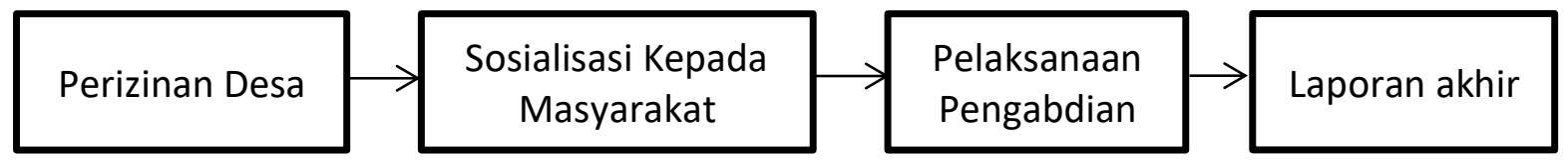

Pada pelaksanaan pengabdian tersebut, tim dosen Universitas Bumigora membawakan beberapa materi antara lain:

1. Bidang Produksi

Berdasarkan permasalahan produksi yang telah dihasilkan oleh kelompok usaha bersama di Desa Kumbung yang masih sangat terbatas dan sedikit serta kurangnya keterampilan ibu-ibu dan remaja putri dalam mengolah dan menyajikan makanan berbahan baku ikan air tawar, pengetahuan mengenai cara produksi makanan yang 
baik masih kurang, kami memberikan solusi untuk menambah aneka ragam olahan dari ikan lele untuk dipasarkan di masyarakat luas dengan cara mengadakan Pelatihan peningkatan kreatifitas kelompok usaha bersama. Kegiatan ini memberikan informasi dan pengetahuan melalui menyajian presentasi dan diskusi terkait bagaimana cara memanfaatkan pangan lokal dari ikan lele untuk dapat dijadikan berbagai macam hasil olahan seperti mie, siomay,nuget, sosis dan stick ikan lele. Dijelaskan juga terkait resep dan teknik pengolahan agar tetap terjaga hygiene dan sanitasi hasil olahan. Selain itu dijelaskan terkait teknik pengemasan dan cara membuat desain kemasan untuk produk yang sudah jadi hingga bagaimana cara pemasaran secara online (e-commerce). Mitra dalam hal ini kelompok usaha bersama diberikan modul yang berisi materi-materi yang telah disampaikan narasumber dari dosen-dosen Universitas Bumigora untuk dapat dijadikan pedoman dalam melaksanakan usahanya.

2. Bidang manajemen

Mitra kelompok usaha bersama Desa Kumbung belum memiliki manajemen usaha. Oleh karena itu, kami memberikan informasi melalui pelatihan dan pembentukan tim manajemen untuk mengatur dan mengelola kegiatan manajemen hasil oalahan ikan lele. Demi mewujudkan keberhasilan usaha, pelaku usaha harus memiliki seorang leader atau kepala untuk dapat mengatur dan mengontrol kegiatan usaha. Pada kegiatan ini terbenttuk susunan organisasi manajemen kelompok usaha bersama Desa Kumbung. Dalam manajemen usaha, dibagi menjadi beberapa bidang atau bagian yaitu tim produksi, tim pengemasan dan tim pemasaran. Dijelaskan juga terkait jobdesk masing-masing agar beban kerja yang ditanggung ideal dalam mengemban tugas. Masing-masing bidang harus berkoordinasi dengan ketua dan anggotanya. Skill komunikasi dalam hal ini sangat dibutuhkan. Diberikan juga ilmu terkait bagaimana teknik berkimunikasi dengan baik dengan sesama tim dan juga kepada masyarakat.

3. Bidang pemasaran

Kegiatan pemasaran produk pada kelompok usaha bersama Desa Kumbung masih sangat terbatas, produk yang dihasilkan dijual kepada masyarakat sekitar, ke keluarga dan teman-teman yang ada di kota mataram dan sekitarnya. Oleh karena itu, kami memberikan solusi untuk dapat mengembangkan pemasaran yang jauh lebih luas dari sebelumnya dengan metode e-commerce yaitu suatu teknik pemasaran dengan menjual produk yang dihasilkan secara online. Dengan metode ini, mitra yaitu kelompok usaha bersama Desa Kumbung akan lebih mudah dan simple untuk menjual produk dari rumah sendiri, tidak perlu mendirikan toko/ruko. Cukup bermodal smartphone dan kuota internet sudah dapat memasarkan produk 
melalui media online. Dalam bidang pemasaran juga diberikan penyampaian materi dan praktek bagaimana caranya membuat situs untuk dapat menjual produk di media online. Kelompok usaha bersama Desa Kumbung akan diajarkan secara langsung membuat desain kemasan, pembuatan situs/web penjualan hingga cara kerjasama dalam pengiriman produk tersebut. Dengan adanya metode penjualan secara online (e-commerce) ini, diharapkan pangsa pasar akan jauh lebih luas hingga ke luar pulau lombok sperti pulau Sumbawa, Bali dan Jawa hingga ke seluruh daerah di Indonesia. Metode ini lebih simple, praktis dan ekonomis dibandingkan dengan kelompok usaha bersama menjual secara langsung produkproduk seperti yang selama ini telah dilakukan. Dengan adanya kemjuan teknologi di era revolusi industri 4.0, sangat diharapkan masyarakat khususnya usaha bersama Desa Kumbung dapat melek teknologi dan mampu persaing dengan pelaku UMKM di luar sana sehingga dapat mengangkat perekonomian keluarga dan Desa Kumbung.

Partisipasi mitra dalam pelaksanaan program dilibatkan langsung dari awal perencanaan kegiatan hingga berhasil melakukan pemasaran berbagai macam produk yang telah dihasilkan oleh kelompok usaha bersama Desa Kumbung. Mitra akan melakukan praktek secara langsung bagaimana teknik pengolahan ikan lele untuk dapat dijadikan berbagai macam hasil olahan dan dapat dikemas dengan baik serta cara pemasaran di media online untuk dapat mewujudkan program PKM ini yaitu memberikan solusi untuk mengurai permasalahan perekonomian di Desa Kumbung dalam memanfaatkan ikan lele yang berlimpah. Setelah program ini berhasil berjalan, tidak lepas dari kegiatan evaluasi. Langkah evaluasi pelaksanaan program dan keberlanjutan program setelah kegiatan Pengabdian Kepada Masyarakat selesai dilaksanakan yaitu melihat bagaimana hasil yang dicapai oleh mitra kelompok bersama Desa Kumbung, apabila belum berhasil perlu dilakukan perbaikan-perbaikan metode atau langkah-langkah dalam pengolahan bahan pangan local, manajemen cara pengemasan dan teknik pemasaran. Diharapakn program ini dapat berlanjut dan dilakukan secara berkala untuk memberikan refresing ilmu pengetahuan guna meningkatkan keterampilan dan ilmu pengetahuan kelompok usaha bersama Desa Kumbung demi mewujudkan kesejahteraan kelompok usaha bersama dan masyarakat Desa Kumbung.

\section{Pembahasan}

Pengabdian masyarakat yang dilakukan di Dusun Pondok Buak, Desa Batu Kumbung, Kecamtan Lingsar, Kabupaten Lombok Barat, menghasilkan beberapa hal terkait penyampaian informasi tentang pengolahan lele antara lain: 
a. Pembuatan olahan pangan dari produk lele

Pengabdian masyarakat yang dilakukan di Dusun Pondok Buak, Desa Batu Kumbung, Kecamtan Lingsar, Kabupaten Lombok Barat, pada tahapan penyampaian informasi tentang pengembangan makanan atau produk olahan dari bahan baku ikan lele. Pengembangan olahan makanan ikan lele, masyarakat Dusun Pondok Buak sangat antusias untuk membentuk kelompok usaha guna mengembangkan produk makanan berbahan baku ikan lele (RI, 2014).
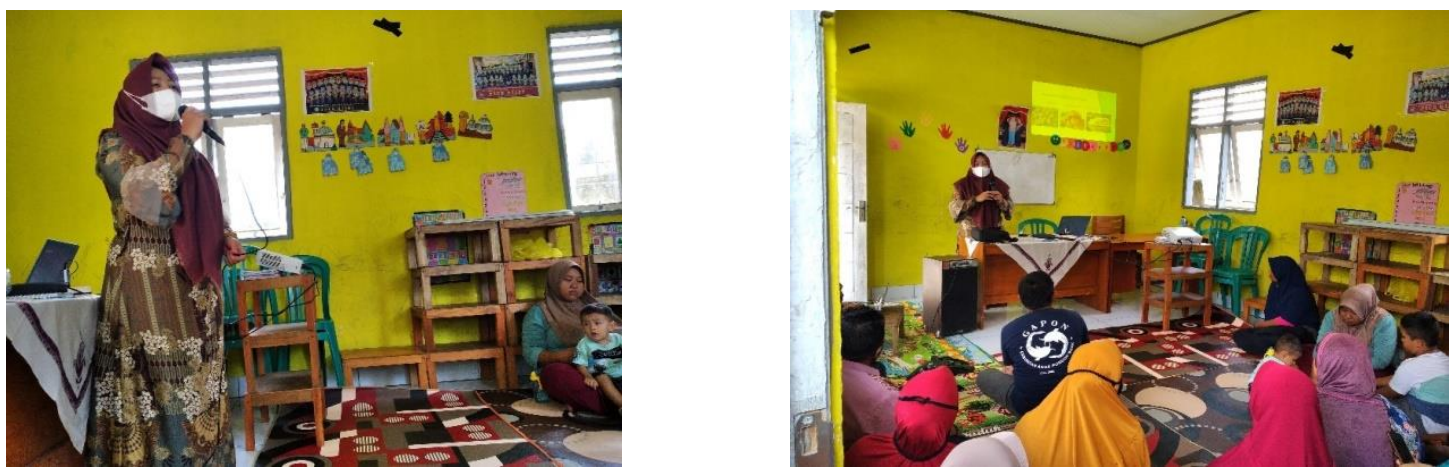

Gambar 1. Pemaparan materi dan diskusi

Pemaparan materi tentang manfaat dan kandungan gizi dalam ikan Lele yang diikuti oleh \pm 25 peserta dari kelompok usaha dan kelompok calon wirausaha di Dusun Pondok Buak Desa Batu kumbung. Kelompok usaha yang mengikuti kegiatan tersebut, sangat antusias terutama tentang kelebihan manfaat dan gizi yang terkandung dalam Ikan lele.

Tabel 1. Kandungan gizi ikan lele per 100 gram

\begin{tabular}{cc}
\hline Zat Gizi & Berat \\
\hline Protein & 18 gram \\
Lemak & 3 gram \\
Natrium & 50 gram \\
Omega-3 & 237 miligram \\
Omega-6 & 337 miligram \\
Zat Besi & 5,6 gram \\
\hline
\end{tabular}

Sumber : DKBM 2017

Kandungan gizi dalam ikan lele memiliki 18 gram protein, 3 gram lemak, 50 gram natrium, 237 miligram asam lemak omega-3, 337 miligram asam lemak omega-6 dan 5,6 gram zat besi. Berdasarkan kandungan gizi dari ikan lele, dapat diolah menjadi beberapa olahan makanan yang tawarkan dari bahan baku ikan lele (Singh, 2016).

Hasil diskusi tentang olahan makanan yang ditawarkan kepada kelompok usaha di dusun Pondok Buak, Desa Batu Kumbung. Makanan olahan yang dihasilkan berupa Mie Lele, Siomay Lele, Stick Lele, Cilok Lele, Sosis lele, Nugget lele, Sosis lele.

b. Desain Kemasan Olahan Makanan Ikan Lele 


\section{ADMA}

Qurnal Pengabdian dan Pemberdayaan Masyarakat
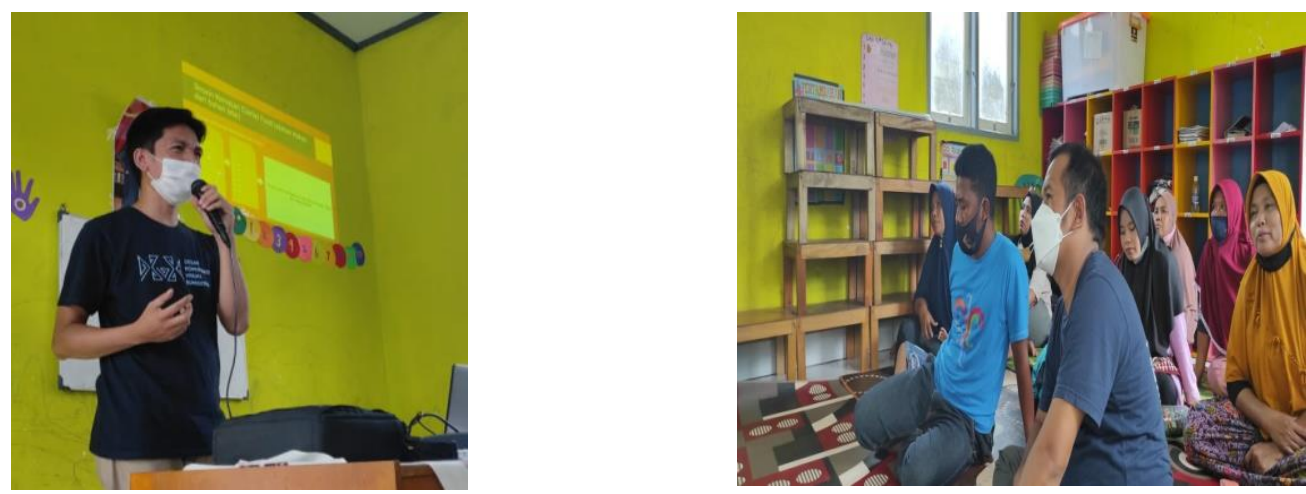

Gambar 2. Pemaparan materi tentang desain kemasan

Desain kemasan diperkenalkan bertujuan untuk menambah nilai jual sebuah produk olahan ikan lele. Produk-produk tersebut menjadi popular di kalangan masyarakat luas karena dikemas dengan desain yang menarik, sehingga menjadi laku di pasaran. Dengan adanya usaha makanan olahan dari bahan baku ikan lele, dan didukung oleh nilai kemas yang menarik dapat meningkatkan omset kelompok usaha masyarakat di Dusun Pondok Buak.(Saraswati \& Hardinsyah, 2016)

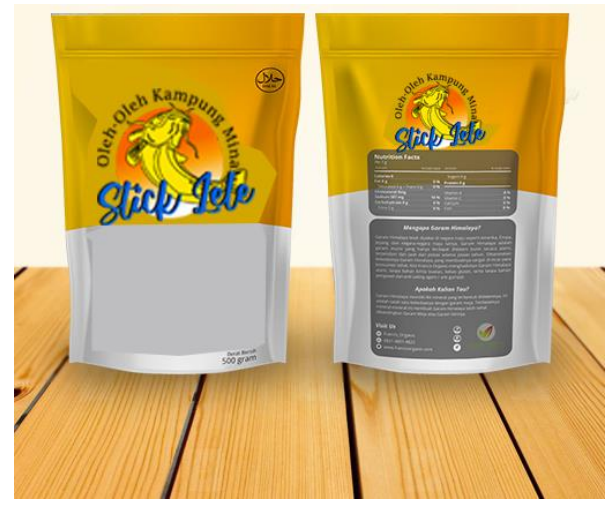

Gambar 3. Hasil rancangan desain kemasan

\section{c. Pemasaran Online}

Setelah produk olahan ikan lele di kemasa dengan menarik selanjutnya, pembinaan masyarakat atau kelompok usaha mengenai pemasaran online. Pasar digital menjadi sorotan dekade ini, dikarenakan penggunaan media sosial semakin menjamur. Pemanfatan media sosial secara positif dan menguntungkan, itulah menjadi target dalam hal ini. 


\section{ADMA}

Gurnal Pengabdian dan Pemberdayaan Masyarakat
2022, Vol.2, No.2, pp.169-178

Doi: 10.30812/adma.v2i2.1578

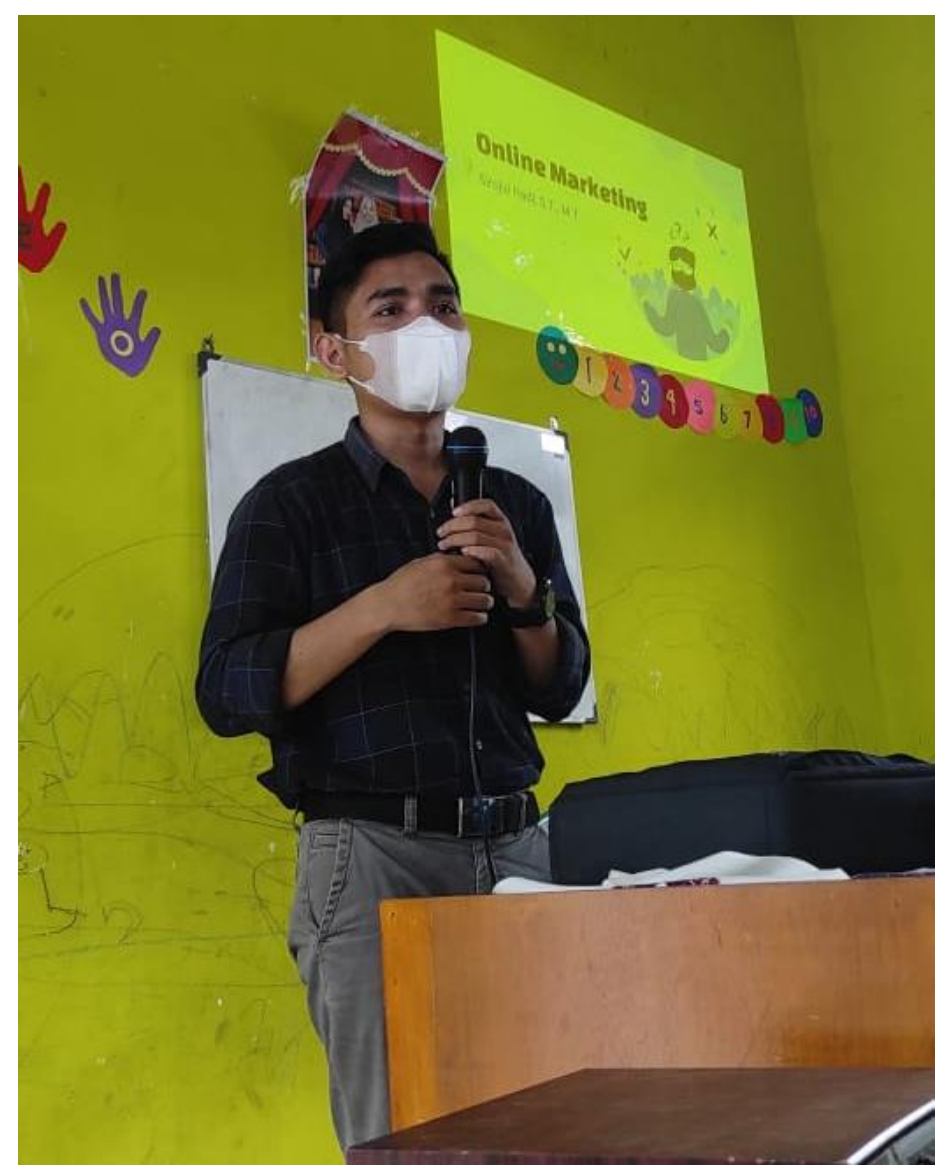

Gambar 4. Pemaparan materi tentang pasar online

Pasar online (online marketing) menjadi pilihan saat ini, terutama saat pandemi ini masyarakat menjadi dimanjakan oleh berbagai platform pasar digital yang sudah ada, tak kalah pentingnya di Desa Batu Kumbung sendiri sudah memiliki situs pasar online yang dinamakan Warung Desa "WARDES" sebagai sentra pemasaran produk hasil olahan makanan berbahan baku ikan lele (Muhammad, 2014).

\section{Kesimpulan}

Berdasarkan pengabdian masyarakat yang telah dilakukan maka dapat disimpulkan bahwa pemberian materi pelatihan telah dilaksanakan dengan materi pelatihan yang diberikan berupa bagaimana membuat produk dari bahan olahan ikan lele sehingga menjadi produk yang mempunyai nilai gizi tinggi dan dapat di pasarkan ke masyarakat. Selain itu, untuk menarik minat pembeli terhadap produk yang dipasarkan maka kami juga memberikan pelatihan bagaimana membuat desain kemasan yang menarik dan unik sebagai ciri khas dari produk yang di buat. Minimnya pengetahuan warga tentang pemasaran digital, maka kami telah memberikan pelatihan pemasaran online untuk meningkatkan jumlah pembeli dan mengatasi pengurangan biaya operasional khususnya untuk pembuatan toko atau penyewaan toko. Kegiatan pengabdian ini dapat dilakukan secara regular dengan waktu 
yang disepakati oleh pihak desa dan Universitas Bumigora agar pengembangan hingga pemasaran produk dapat didampingi oleh Tim Dosen Universitas Bumigora. Hasil yang didapatkan dapat menjadi salah satu alternatif produk bagi UMKM yang dapat dipasarkan melalui media online e-commerce yang telah dimiliki oleh Desa.

\section{Ucapan Terimakasih}

Terimakasih kami sampaikan kepada Bapak Kepala Desa Batu Kumbung dan Bapak Kepala Dusun Pondok Buak yang telah memberikan kami izin melakukan pengabdian di wilayah kerjanya.

\section{Daftar Pustaka}

Arni Muhammad. (2014). Komunikasi Organisasi. PT. Bumi Aksara.

Badan POM. (2018). Iaporan Tahunan Tahun 2018. Laporan Tahunan Kegiatan Tahun 2018, 192.

Baiq Fitria Rahmiati. (2019). Upaya Perbaikan Status Gizi Balita Melalui Sosialisasi Menu Mp-Asi Sesuai Usia Balita Di Kecamatan Gunungsari. JPMB: Jurnal Pemberdayaan Masyarakat Berkarakter, 2(2), 138-145. https://doi.org/10.36765/jpmb.v2i2.8

Eko Suparmiyati et al. (2017). Pusat analisis dan evaluasi hukum nasional badan pembinaan hukum nasional kementerian hukum dan hak asasi manusia r.i tahun 2017.

IKP, B. (2020). NTB Kembangkan 4 Strategi Atasi Stunting. Pemerintah Provinsi Nusa Tenggara Barat.

Notoatmodjo, S. (2003). Pendidikan dan perilaku kesehatan.

Rahmiati, B. F., Briawan, D., \& Madanijah, S. (2018). Studi Kualitatif Tentang Faktor Dan Strategi Perbaikan Program Suplementasi Besi Ibu Hamil Dengan Kasus Di Kabupaten Tasikmalaya. Media Gizi Mikro Indonesia, 9(2), 113-122. https://doi.org/10.22435/mgmi.v9i2.619

RI, K. (2014). Profil Kesehatan Indonesia 2014.

Saraswati, M. M. D., \& Hardinsyah, H. (2016). Pengetahuan Dan Perilaku Konsumsi Mahasiswa Putra Tingkat Persiapan Bersama Ipb Tentang Monosodium Glutamat Dan Keamanannya. Jurnal Gizi Dan Pangan, 7(2), 111. https://doi.org/10.25182/jgp.2012.7.2.111-118

Singh, K. (2016). Nutrient and Stress Management. Journal of Nutrition \& Food Sciences, 6(4). https://doi.org/10.4172/2155-9600.1000528 


\section{ADMA}

Jurnal Pengabdian dan Pemberdayaan Masyarakat
2022, Vol.2, No.2, pp.169-178

Doi: $10.30812 / a d m a . v 2 i 2.1578$ 